\title{
Wiesław Caban
}

https://orcid.org/0000-0002-3695-8259

Uniwersytet Jana Kochanowskiego w Kielcach

\section{Oktawian Jeleński - Polak w carskim mundurze. O Rosjanach i relacjach polsko-rosyjskich w XIX wieku*}

Zarys treści: Oktawian Jeleński z pozycji oficera armii carskiej charakteryzuje społeczeństwo rosyjskie w latach czterdziestych-osiemdziesiątych XIX w. Opisuje stosunek elit rosyjskich do powstania styczniowego. Poddaje krytyce politykę Rosji wobec Polaków zamieszkałych na Ziemiach Zabranych. Jego zdaniem Polak daleko mocniej odczuwał tu politykę represji, niż to miało miejsce w głębi Imperium Rosyjskiego.

Outline of content: From his position of tsarist army officer, Oktawian Jeleński characterises Russian society from the 1840 s to the 1880 s. He describes the attitude of the Russian elite to the January Uprising. He criticizes Russia's policy towards Poles living in the Stolen Lands. In his opinion, the Poles here felt the policy of reprisal and victimisation far more strongly than in the depths of the Russian Empire.

Słowa kluczowe: relacje polsko-rosyjskie w XIX w., Oktawian Jeleński, Rosja carska XIX w., Rosjanie wobec powstania styczniowego

Keywords: Polish-Russian relations in the $19^{\text {th }}$ century, Oktawian Jeleński, tsarist Russia of the $19^{\text {th }}$ century, Russian towards the January Uprising

Oktawianem Jeleńskim, a właściwie jego wspomnieniami, które opublikował

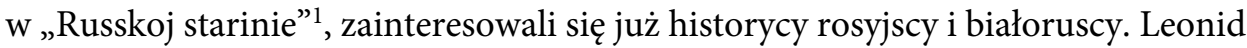

* Tekst przygotowany w ramach realizacji projektu Narodowego Programu Rozwoju Humanistyki, pt. „Pamiętniki i listy polskich autorów z ziem zabranych (Litwa, Białoruś, Ukraina) w latach 1795-1918". Umowa nr 0083/NPRH2/H11/81/2012.

1 О. Еленский, Мои воспоминания о забытом корпусе, „Русская старина” 83 (1895), № 6, s. $143-$ 169; № 11, s. 185-203; idem, Мылси и воспоминания поляка, „Русская старина” 127 (1906), № 11 , s. 670-714; 128 (1906), № 10, s. 200-242. 
Jefriemowicz Gorizontow z Moskwy przywoływał w swej pracy, omawiającej paradoksy w polityce imperialnej Rosji wobec Polski w XIX w., opisy Jeleńskiego przedstawiające prześladowania unitów $\mathrm{w}$ guberniach zachodnich. $\mathrm{Z}$ kolei Irina Juriewna Martianowa z Krasnodaru, w oparciu o wspomnienia Jeleńskiego, przygotowała interesujący tekst na temat sytuacji staroobrzędowców w centralnych guberniach Rosji w połowie XIX w., a dwom historykom białoruskim Piotrowi Iwanowiczowi Brygadninowi i Andriejowi Michajłowiczowi Łukaszewiczowi jego wspomnienia w dużej mierze posłużyły do odtworzenia dziejów kadeckiego korpusu w Brześciu².

Moje zainteresowanie wspomnieniami Jeleńskiego wiąże się z realizacją wskazanego projektu badawczego. Po dotarciu do nich w „Russkoj starinie” postanowiliśmy wspólnie z prof. dr. hab. Jerzym Szczepańskim opublikować je w języku polskim ${ }^{3}$.

O autorze wiemy stosunkowo niewiele. Mianowicie jedynie to, że urodził się 12 września 1838 r. w Borysowie, mieście powiatowym guberni mińskiej; jego rodzice to Rajmund Jan i Michalina z Bodzianowskich. Ojciec był krewnym Feliksa Jeleńskiego, marszałka mozyrskiego, którego synowie Jan i Napoleon zostali aresztowani za udział w spisku Szymona Konarskiego i zesłani na Syberię ${ }^{4}$.

Oktawian miał dwóch braci: Jana Józefa, urodzonego w 1840 r. i Mieczysława Wiktora, urodzonego w $1854 \mathrm{r}$. W $1850 \mathrm{r}$. dwunastoletni chłopiec został wysłany na naukę do powstałego w 1842 r. brzeskiego korpusu kadetów. O powodach takiej decyzji trudno się wypowiadać. Prawdopodobnie rodzice postanowili oddać Oktawiana, a później o dwa lata młodszego Jana ${ }^{5}$, do szkoły wojskowej, gdzie nauka była bezpłatna, bo z jednej strony sytuacja materialna nie pozwalała im na kształcenie dzieci najpierw w Instytucie Szlacheckim w Wilnie, a później na uniwersytecie w Moskwie lub Petersburgu ${ }^{6}$. Ale nie można wykluczać jeszcze innego czynnika. Otóż rodzice Oktawiana, kiedy był on kilkuletnim dzieckiem, zostali aresztowani w wyniku donosu złożonego przez rosyjskiego urzędnika. Matkę dość szybko zwolniono, ojca dopiero po pięciu miesiącach. Okoliczności ich aresztowania nie

\footnotetext{
2 Л.Е. Горизонтов, Парадоксы имперской политики: поляки в России и русские в Польше (ХІХ - начало XX в.), Москва 1999, s. 85, 178; И.Ю. Мартианова, Воспоминания поляка о старообрядиах России (вторая половина ХІХ в.), w: Поляки в России: Эпохи и судьбы, Краснодар 2009, s. 44-50; П.И. Бригадин, А.М. Лукашевич, Мятежный корпус. Из истории Александровского Брестского кадетского корпуса (1842-1863), Минск 2007, s. 183.

${ }^{3}$ Por. O. Jeleński, Rozmyślania i wspomnienia Polaka, oprac. W. Caban, J. Szczepański, w: Mentalność rosyjska a Polska, red. ks. E. Walewander, Lublin 2015, s. 21-72. Opublikowana została część Wspomnień i rozmyślań, zamieszczona w: „Русская старина” 127 (1906), № 11, s. 672-714.

${ }^{4}$ Zob. biogramy w: W. Śliwowska, Zesłańcy polscy w Imperium Rosyjskim w pierwszej połowie XIX wieku, Warszawa 1998, s. 244.

${ }^{5}$ Por. П.И. Бригадин, А.М. Лукашевич, op. cit., s. 159.

${ }^{6} \mathrm{O}$ motywach wstępowania Polaków z Litwy, Białorusi i Ukrainy do szkół wojskowych por. W. Caban, W stużbie imperium, czy ofiary imperium? Polacy $w$ carskim korpusie oficerskim $w$ XIX wieku, w: Ofiary imperium. Imperia jako ofiary. 44 spojrzenia, red. A. Nowak, Warszawa 2010, s. 214-226.
} 
udało się wyjaśnić. Sam Jeleński powiada, że miejscowy horodniczy oskarżył ich o to, że mieli kontakty z jakimś emisariuszem, a donos zrobił dlatego, że rodzice udzielali schronienia jego żonie, którą tyranizował․ Nie można jednakże wykluczyć, że był to dalszy ciąg sprawy, w którą zamieszani zostali Jan i Nepomucen Jeleńscy, kuzynowie Oktawiana. Rodzice Oktawiana uniknęli zsyłki i być może wykalkulowali, że najlepszym dowodem ich lojalności wobec cara będzie wysłanie najstarszego syna do korpusu kadetów ${ }^{8}$.

Oktawian pobierał nauki w korpusie kadetów przez dziewięć lat. Zaczął je w Brześciu, a zakończył w Moskwie w 1859 r., bo w 1854 r. korpus tam właśnie został przeniesiony. Czas nauki wspominał dobrze, do czego jeszcze wrócę.

Następnie wstąpił do pułku stacjonującego w Muromie (ok. $250 \mathrm{~km}$ na wschód od Moskwy). Odtworzenie przebiegu kariery wojskowej jest aktualnie niemożliwe, bowiem nie zachowała się jego lista służby, czyli tzw. posłużnyj spisok. Dokumentacja służby kadry oficerskiej przechowywana jest w Rossijskim Gosudarstwiennym Wojenno-Istoriczeskim Archiwie (RGWIA) w Moskwie. Znajdują się tam posłużnyje spiski aż czterech Jeleńskich, ale żaden z nich nie odnosi się do Oktawiana. Na podstawie jego wspomnień można wnioskować, że służył w pułku, do którego zadań należało pełnienie wart przy budynkach państwowych, w tym także przy więzieniach. Był m.in. dowódcą wart przy więzieniach moskiewskich oraz w Carycynie i Saratowie. W tym ostatnim mieście, jak sam zaznaczył, odbywał służbę w latach 1879-1889. Najprawdopodobniej opuścił ją w 1889 r., bo po 30 latach mógł przejść na emeryturę, ale nie wiadomo, w jakim stopniu odchodził ze służby wojskowej. Ze wspomnień wiemy, że w 1861 r. posiadał stopień porucznika. Można więc spokojnie założyć, że przechodził na emeryturę w stopniu podpułkownika lub pułkownika ${ }^{9}$.

Jesienią 1860 r. jego pułk przeniósł się z Muromia do Moskwy. To przejście zbiegło się z ożywieniem politycznym, które wywołały wydarzenia warszawskie $1861 \mathrm{r}$. i przygotowania do wybuchu powstania styczniowego. Jeleński bywał na różnych spotkaniach, w których uczestniczyła inteligencja Moskwy, młodzież studencka, zarówno polska, jak i rosyjska, a także wielu wojskowych. Pułk Jeleńskiego w Moskwie przebywał w latach 1860-1861, stamtąd udał się do Kostromy, a z całą pewnością od 1879 r. stacjonował w Saratowie.

Jeleński współpracował z ugodowym pismem „Kraj”, założonym przez Erazma Piltza i Władysława Spasowicza w 1882 r. Nie wiadomo, w jakich okolicznościach do tego doszło i jak to było możliwe, że Polak, oficer armii rosyjskiej, współpracował, co prawda z ugodowym, ale z polskim czasopismem. Musiał mieć na to zgodę

7 „Русская старина” 127 (1906), № 11, s. 672. Por. O. Jeleński, Rozmyślania i wspomnienia..., s. 29.

${ }^{8}$ Inaczej do tej kwestii podchodzi И.Ю. Мартианова, ор. cit., s. 45. Jej zdaniem Jeleńscy oddali syna do korpusu kadetów, gdyż obawiali się, że zostanie on wcielony do armii jako rekrut.

9 Autorzy pracy o brzeskim korpusie kadetów w aneksach umieścili informacje o karierach wojskowych wychowanków tegoż korpusu. Niestety o Oktawianie Jeleńskim jest niewiele. Por. П.И. Бригадин, А.М. Лукашевич, op. cit., s. 159. 
najwyższych czynników wojskowych. Natrafiono na podpisane teksty Jeleńskiego zamieszczone w „Kraju” z lat 1887-1888 ${ }^{10}$. Jak zauważył Zenon Kmiecik, autor pracy o „Kraju”, dotyczyły one spraw gospodarczych. Jeleński na łamach tego pisma publikował korespondencje z różnych części Imperium Rosyjskiego, zwłaszcza Powołża, o możliwościach podejmowania tam korzystnych przedsięwzięć gospodarczych przez przemysłowców z Królestwa Polskiego ${ }^{11}$, a także dogodnych warunkach dla osadnictwa chłopów z Galicji, Królestwa i Litwy.

Zarówno wspomnienia o korpusie brzeskim, opublikowane w 1895 r., jak i 11 lat później Rozmyślania i wspomnienia Polaka zawierają wiele ciekawych spostrzeżeń na temat Rosjan i relacji polsko-rosyjskich w XIX w. Jeleński nie poddał się utartym schematom i sądom dominującym zarówno po jednej, jak i po drugiej stronie. Jest jednak pewna trudność w lekturze jego zapisków, a to dlatego, że opisując niektóre zdarzenia $\mathrm{z}$ lat czterdziestych-sześćdziesiątych XIX w., niepostrzeżenie przekazuje swoje refleksje dotyczące relacji polsko-rosyjskich z kilkudziesięcioletniej perspektywy. Stąd też pewne zdarzenia nabierają nieco odmiennego wymiaru. Zdarzają się też pomyłki w odniesieniu do datacji poszczególnych wydarzeń i błędy w zapisach nazwisk.

U Jeleńskiego już we wczesnym dzieciństwie pojawiła się niechęć i strach do wszystkiego, co rosyjskie za sprawą rządów Iwana Paskiewicza, namiestnika Królestwa Polskiego w latach 1832-1856 i Dmitrija Bibikowa, gubernatora kijowskiego, podolskiego i wołyńskiego w latach 1837-1852. Ich rządy, jak podkreślał, budziły strach i przerażenie u wszystkich, nawet najsilniejszych ludzi. Dodatkowo strach u niego przed Rosją potęgowały obrazy wywożonych Polaków w kibitkach na Sybir. Tak się złożyło, że dom, w którym mieszkał w dzieciństwie w Borysowie, stał obok stacji pocztowej i kilkuletni chłopiec widział wielokrotnie takie obrazy ${ }^{12}$.

Jak wspominałem, w 1850 r. Jeleński trafił do korpusu kadeckiego w Brześciu. Byłem zaskoczony lekturą tej części wspomnień, bowiem w historiografii polskiej, nieustannie za Agatonem Gillerem, powtarza się, że warunki bytowe panowały

10 Zob. O. Jeleński, Przemysł naftowy w Rosyi, odbitka „Kraju” (1888); Z. Kmiecik, „Kraj” za czasów redaktorstwa Erazma Piltza, Warszawa 1969; Z. Łukawski, Ludność polska w Rosji 1863-1914, Wrocław 1978, s. 43, przypis 2. Niewykluczone, że ta współpraca mogła zacząć się już w 1883 r., a sądzę to tak na podstawie niepodpisanej Korespondencji z Besarabii, „Kraj” (1883), nr 4. Erazm Piltz w pierwszym okresie funkcjonowania czasopisma miał ogromne kłopoty ze znalezieniem odpowiednich współpracowników, zwłaszcza takich, którzy nadsyłaliby korespondencje dotyczące życia Polaków w różnych częściach Imperium Rosyjskiego. Być może inicjatywa wyszła od samego Jeleńskiego, a Piltz tylko ją zaakceptował.

${ }^{11} \mathrm{Na}$ jedną z jego korespondencji krytycznie zareagowała redagowana przez Aleksandra Świętochowskiego „Prawda. Tygodnik Polityczny, Społeczny i Literacki” (1888), nr 52, s. 622. Czy krytyka była słuszna, trudno mi to ocenić. Świętochowski popadł w konflikt z Piltzem i być może słabszy tekst Jeleńskiego dał pośredni powód do krytyki jego pisma.

12 „Русская старина” 127 (1906), № 11, s. 671-672. Por. O. Jeleński, Rozmyślania i wspomnienia..., s. 29. 
tam okropne, poziom nauczania fatalny, a licznie zgromadzoną polską młodzież poddawano systematycznej rusyfikacji ${ }^{13}$.

Korpus kadecki w Brześciu utworzono w 1842 r. na wniosek szlachty polskiej z guberni zachodnich i do 1848 r. młodzież z polskich rodzin stanowiła $2 / 3$ kadetów, a $1 / 3$ z guberni wielkoruskich. W okresie Wiosny Ludów przyjęto zasadę, że 50\% miejsc zostanie przeznaczonych dla młodzieży polskiej, a 50\% - dla młodzieży rosyjskiej z guberni wielkorosyjskich ${ }^{14}$. Ta zmiana była podyktowana tym, że w korpusie w czasie Wiosny Ludów dochodziło do tajnych rozmów między kadetami na tematy wydarzeń zachodzących w Europie.

Oktawian Jeleński stawiał w zupełnie innym świetle ten brzeski korpus. Wiele miejsca poświęcił kadrze oficerskiej i nauczycielom wykładającym poszczególne przedmioty, ale zarazem dodawał, że wśród kadry nauczającej była tylko jedna osoba z wykształceniem uniwersyteckim. Nie skarżył się na poziom prowadzonych zajęć przez innych nauczycieli. Zastrzeżenia miał tylko do jednej osoby, ale nie wymienił jej z imienia i nazwiska. Musiała to być osoba niezwykle prymitywna, skoro została zwolniona przez władze zwierzchnie i skierowana do służby w policji.

Jeśli chodzi o relacje między Polakami a Rosjanami, to najpierw we wspomnieniach opublikowanych w 1895 r. stwierdził, że nie przypomina sobie, by przez 9 lat pobytu w korpusie doszło do jakichś incydentów na tle narodowościowym czy religijnym. Natomiast we wspomnieniach wydanych w 1906 r., wracając do spraw brzeskiego korpusu, napisał, że początkowo Polacy nie trzymali się z rosyjskimi kolegami, ale pod koniec pobytu wszyscy żyli w zgodzie i przyjaźni ${ }^{15}$. A w ogóle stwierdził, że brzeski korpus kadetów mógł służyć za wzór, jak wychowywać polską młodzież, aby panowała harmonia między dwoma bratnimi narodami ${ }^{16}$.

Z rozważań Jeleńskiego można wnioskować, że na te dobre relacje między kadetami narodowości polskiej i rosyjskiej miały wpływ dwa czynniki. Władze korpusu nie ustalały specjalnego nadzoru nad Polakami i mogli oni czytać książki polskich autorów. Jeleński wymienił m.in. Juliana Ursyna Niemcewicza i Joachima Lelewela. Ważną rolę w zbliżaniu się dwu narodowości mieli odegrać nauczyciele religii prawosławnej i katolickiej. Autor wskazał z jednej strony ojca Gorizontowa, a z drugiej - ks. Adama Koźmiana, kanonika kolegiaty wileńskiej. Obaj duchowni żyli w przyjaźni i w ten sposób dawali przykład kadetom ${ }^{17}$.

W tym samym korpusie, ale na wyższym kursie nauki pobierał Jarosław Dąbrowski, starszy od Jeleńskiego o dwa lata. Dąbrowski już wtedy angażował się w działalność patriotyczną. Nie ulega wątpliwości, że między Dąbrowskim

13 Por. A. Giller, Korpus Kadetów w Brześciu Litewskim, w: idem, Z wygnania, t. 1, Lwów 1870, s. 33-60. Białoruscy autorzy pracy o korpusie brzeskim nie znali publikacji Gillera. Por. też: J. Zdrada, Jarosław Dąbrowski 1836-1871, Kraków 1973, s. 20-29.

14 „Русская старина” 83 (1895), № 6, s. 147. Por. П.И. Бригадин, А.М. Лукашевич, op. cit., s. 56.

15 „Русская старина” 83 (1895), № 6, s. 147; 127 (1895), № 11, s. 674.

16 Ibidem.

17 „Русская старина” 83 (1895), № 6, s. 157. 
a Jeleńskim doszło do rozmów na tematy związane z wyborem drogi, która doprowadziłaby Polskę do odzyskania niepodległości. Jeleński bardzo krótko odniósł się do tych spraw, stwierdzając, że fantazje Dąbrowskiego sięgały „siódmego nieba” 18 .

W 1854 r. korpus przeniesiono do Moskwy. Warunki życia kadetów znacznie się zmieniły, bo po klęsce Rosji w wojnie krymskiej i śmierci Mikołaja I zapanowała inna atmosfera polityczna. Trzeba dodać, że w korpusie doszło do zmian jeszcze z jednego powodu. Otóż wraz z koronacją w 1855 r. Aleksandra II korpus przyjął nazwę Aleksandryjski Brzeski Kadecki Korpus i wychowankowie w miarę swobodnie mogli uczestniczyć w życiu towarzyskim Moskwy. Jeleński zaprzyjaźnił się $\mathrm{z}$ bliżej mi nieznaną rodziną Aleksiejewych i brał udział w wieczorach organizowanych w tym domu. Zbierało się tu wiele osób o liberalizujących poglądach. Między innymi na jednym $\mathrm{z}$ takich wieczorów zawarł znajomość z Jewgienijem Korszem, redaktorem postępowego miesięcznika „Ateneum”, wychodzącego w latach 1856$1858^{19}$. Na innym ze spotkań towarzyskich poznał Michaiła Katkowa, ale jak zaznaczył, zachowywał się on wtedy bardzo skromnie ${ }^{20}$. Często bywał w domach młodych Polaków studiujących na Uniwersytecie Moskiewskim i od nich nauczył się polskich pieśni.

Po ukończeniu w 1859 r. korpusu kadeckiego Jeleński poprosił dowództwo, by skierowano go do pułku stacjonującego w centralnej Rosji, bo chciał koniecznie poznać, jak żyje się na rosyjskiej prowincji. Został więc skierowany do pułku, którego sztab stacjonował w Muromie w guberni włodzimierskiej, a poszczególne bataliony były rozlokowane po wsiach. Stworzyło to rzeczywiście możliwości do obserwacji zachowania poszczególnych warstw i grup społecznych żyjących na prowincji Rosji. W latach 1860-1861 pułk stacjonował w Moskwie i Jeleński mógł poszerzyć pole obserwacji. W Rozmyślaniach i wspomnieniach Polaka dokonał charakterystyki życia wojskowych na prowincji, ziemiaństwa, chłopów, kupiectwa, rosyjskich kobiet, duchowieństwa prawosławnego. Nadto wiele uwagi poświęcił relacjom polsko-rosyjskim $\mathrm{w}$ dobie powstania styczniowego, a także staroobrzędowcom i unitom, lecz tych dwu ostatnich kwestii nie będziemy podejmować, bo zostały one już omówione przez Irinę J. Martianową i Leonida J. Gorizontowa ${ }^{21}$.

Charakterystykę kadry oficerskiej rozpoczął od stwierdzenia, że była to kadra „starej służby, starej daty” i nie interesowała się, w jakim kierunku pójdzie Rosja

18 Ibidem, s. 147. Por. J. Zdrada, Jarosław Dąbrowski..., s. 20-29.

19 Jeleński mylnie podał, że „Ateneum” redagował Walentin Fiodorowicz Korsz. Ten ostatni był w latach 1856-1862 redaktorem „Moskowskich wiedomosti”. Wracając do „Ateneum”, warto pokreślić, że ukazało się tylko 16 numerów pisma. Upadło ono w 1858 r., dlatego że było zbyt postępowe i nie znaleziono odpowiedniej liczby abonentów.

20 „Русская старина” 83 (1895), № 11, s. 197.

${ }^{21}$ Nadto w jego wspomnieniach jest wiele ciekawych spostrzeżeń dotyczących życia społeczeństwa rosyjskiego. Trudno o nich wspominać w tym tekście. Warto może tylko nadmienić, że nie krytykował on wszechobecnego łapownictwa, gdyż uważał, że jeżeli w państwie obowiązuje „dzikie prawo", to łapówka spełnia pożyteczną rolę, bo wiele spraw można załatwić zwyczajnie po ludzku. Sam korzystał z tego typu rozwiązań. 
po przegranej wojnie krymskiej i objęciu tronu przez Aleksandra II. Dla niej liczyły się jedynie obiady proszone przez okoliczne ziemiaństwo czy kupiectwo Muromia. Zajmowała się głównie grą w karty i piciem wódki. Spośród 10 oficerów sztabowych tylko u jednego zachowały się pojedyncze egzemplarze "Ateneum” z 1858 r. A w ogóle Jeleński stwierdził, że w tym czasie oficerowie, jak i społeczeństwo na prowincji Rosji czytać nie lubiło, a najlepiej o tym świadczy brak biblioteki w Muromie ${ }^{22}$.

Jeleński wiele miejsca poświęcił praktykom stosowanym przez oficerów w stosunku do chłopów, u których na kwaterach przebywali żołnierze. Zgodnie z przepisami włościanie za kwaterunek żołnierzy i dostawianie podwód mieli otrzymywać odpowiednie rekompensaty. Tymczasem oficerowie ich nie wypłacali, a należące się chłopom pieniądze zwyczajnie sobie przywłaszczali. Lud wiejski był bezradny wobec takich praktyk i podczas prawie dwuletniej służby w Muromie Jeleński odnotował tylko jeden przypadek, że chłopi zbuntowali się przeciw takiemu wyzyskowi i ostatecznie pieniądze im wypłacono ${ }^{23}$.

Pod koniec pobytu w Muromie w kadrze oficerskiej nastąpiły wyraźne zmiany. Przede wszystkim zwolniono 20 oficerów „starej daty”, spośród 70, a ich miejsca zajmowali wychowankowie korpusów kadeckich ${ }^{24}$, którzy myśleli o dalszym kształceniu w akademiach wojskowych. Wraz z ich pojawieniem się znikły pijaństwa, gra w karty stawała się coraz rzadsza, a czas wolny spędzano w kółkach na dyskusjach i czytaniu m.in. prac Karla Georga Büchnera ${ }^{25}$, Karola Darwina, Ernesta Renana, Johna Stuarta Milla, Herberta Spencera. Zaprenumerowano też „Kołokoła"26 i inne wydawnictwa zagraniczne. Oczywiście dyskutowano, w jakim kierunku pójdą zmiany w samej Rosji.

Tak się złożyło, że w kółku dyskusyjnym, w którym uczestniczył Jeleński, pojawiło się kilku wychowanków brzeskiego korpusu. Wszyscy byli Rosjanami i z nimi właśnie prowadził on dyskusje na tematy historyczne. Szybko nabrali przekonania, że nauka historii w Brześciu, zwłaszcza nauka historii Polski, była prowadzona w sposób zafałszowany. Jeleński rozumiał, że można mieć różne punkty widzenia na poszczególne wydarzenia, ale nie należy kłamać, bo kłamstwo na koniec przynosi rezultaty odwrotne od oczekiwanych. Na poparcie tego stwierdzenia podał fakt,

22 „Русская старина” 127 (1906), № 11, s. 676. Por. O. Jeleński, Rozmyślania i wspomnienia..., s. 33.

23 „Русская старина” 127 (1906), № 11, s. 701.

${ }^{24}$ Jeleński wyraził oburzenie, że władze centralne nie zabezpieczyły odpowiednich warunków bytowych zwalnianym masowo oficerom. W $1861 \mathrm{r}$. przebywając w Moskwie, widział na ulicy wielu wysokich rangą oficerów, którzy zwyczajnie żebrali. Podobnie jego zdaniem było w Petersburgu. Ibidem, s. 704.

${ }^{25}$ Karl Georg Büchner (1813-1837), niemiecki rewolucjonista, pisarz i przyrodnik. W $1834 \mathrm{r}$. wydał ulotkę Pokój chatom! Wojna pałacom!, w której nawoływał ludność Hesji do rewolucji. W 1835 r. ukazał się dramat Śmierć Dantona.

26 Rewolucyjno-demokratyczne czasopismo wydawane w latach 1857-1867 przez Aleksandra Hercena i Nikołaja Ogariowa, początkowo w Londynie, a później w Genewie. Było szeroko rozpowszechniane w Rosji. 
że spośród dziewięciu osób należących do jego kółka w 1863 r. dwie z nich wzięły przepustki i poszły do powstania styczniowego, a trzy kolejne zajęły się literaturą i historią, demaskując kłamstwa oficjalnej rosyjskiej „patriotycznej historiografii”27.

Zdaniem Jeleńskiego „patriotyczna propaganda” nie była znana przeciętnemu ludowi. Jako dowód podał, że w różnych ludowych rosyjskich pieśniach i anegdotach czy $\mathrm{w}$ amatorskich przedstawieniach teatralnych wyśmiewa się Żydów, Niemców, Anglików, a nawet Francuzów, ale Polaków nigdy albo bardzo rzadko, a wszystko dlatego, „że naród rosyjski żyje wyczuciem, a prawdy doszukuje się zmysłami"28.

Jeżeli chodzi o ziemiaństwo, uznał, że można byłoby spisać całe tomy dotyczące różnych form zezwierzęcenia „rosyjskiego jaśniepaństwa”. Przede wszystkim nie mógł zrozumieć, dlaczego dziedzice $\mathrm{z}$ tak wielką przyjemnością na każdym kroku upokarzali chłopa. Ziemiaństwo rosyjskie dla rozrywki wymierzało chłopu niezasłużone rózgi czy też potrafiło wrzucić do dziegciu, a później do puchu i cieszyć się z dziwacznego wyglądu „mużika”. Jego zdaniem tego typu zabawy mogły wymyśleć tylko osoby w pijackim widzie. Opisał też przypadki oddawania na poczet poboru do wojska osób, które w jakikolwiek sposób okazywały swe niezadowolenie $\mathrm{z}$ ucisku. Można by podać wiele drastycznych przykładów zachowania rosyjskiego dziedzica wobec chłopa, ale wydaje się to zbyteczne, bo nie różnią się one od opisanych zarówno przez historyków, jak i w literaturze, zwłaszcza przez Nikołaja Gogola i Michaiła Sałtykowa-Szczedrina ${ }^{29}$.

Ukazując nieludzkie obchodzenie się z chłopami przez dziedziców rosyjskich, nie mógł Jeleński odnieść się do sprawy traktowania włościan przez magnaterię polską. Był świadom, że w historiografii rosyjskiej napisano wiele na temat buntów na Ukrainie w XVII-XVIII w. Przyznał, że dziedzic polski, tak samo jak rosyjski, nieludzko postępował z chłopem. Mimo wszystko stanął po stronie polskiej magnaterii. Uznał, że dziedzic rosyjski upokarzał chłopa dla „uciechy i pijackiego zadowolenia”. Natomiast nieludzkie traktowanie chłopa przez polskiego magnata wynikało z innych pobudek. Chłopi ukraińscy byli dla polskiego dziedzica wrogiem politycznym i religijnym i temu wrogowi należało się przeciwstawić ${ }^{30}$.

A w ogóle, zdaniem Jeleńskiego, ziemiaństwo rosyjskie zajmowało się jedynie grzybobraniem, jazdą konną, grą w karty i urządzaniem balów, a raczej potańcówek. Te ostatnie najczęściej organizowali ziemianie, którzy mieli córki na wydaniu. Rosyjski dziedzic czytał niewiele lub wcale i nie zajmował się w ogóle sprawami społecznymi. Zbliżająca się reforma uwłaszczeniowa chłopów była dla niego niewyobrażalna, więc dyskusji nie podejmowano. Jeżeli ten problem pojawił się na jakimś spotkaniu towarzyskim, to sprawę szybko kwitowano, powiadając, że

27 „Русская старина” 127 (1906), № 11, s. 708. Por. O. Jeleński, Rozmyślania i wspomnienia..., s. 55-56.

28 „Русская старина” 127 (1906), № 11, s. 675.

${ }^{29} \mathrm{Z}$ treści wspomnień wynika, że Jeleński dobrze znał utwory tych pisarzy.

30 „Русская старина” 127 (1906), № 11, s. 699. 
wszystkiemu jest winne polskie ziemiaństwo z guberni zachodnich, które wymusiło na Aleksandrze II podjęcie reformy uwłaszczeniowej ${ }^{31}$.

Jeleński jeszcze bardziej, niż w stosunku do ziemiaństwa, był krytyczny wobec kupców. W jego opinii to ludzie ciemni i pozbawieni jakiejkolwiek uczciwości ${ }^{32}$. Zaraz jednakże zastrzegał się, że nie może się wypowiadać na temat kupiectwa całej Rosji, a jedynie tego, które poznał w Muromie. Tamtejsi kupcy na ogół byli niepiśmienni, a swoje rachunki prowadzili za pomocą stawianych kresek na specjalnie przygotowanych laskach. Powszechne były oszustwa, a w ogóle trudno mówić o handlu na poziomie europejskim.

Każdy kupiec starał się mieć na wsi reprezentacyjny pałac, do którego zapraszano gości, by pochwalić się swym bogactwem. Pałac dzielił się na dwie części: reprezentacyjną i zamieszkałą przez gospodarzy. Tę pierwszą udostępniano tylko dla gości. Część zamieszkała przez gospodarzy była wyposażona w proste, tanie meble, a z brudnych pokoi dolatywały nieprzyjemne zapachy. Kupiectwo Muromia nie interesowało się problemami społecznymi. Kiedy Jeleński zetknął się z kupiectwem Moskwy, to nie wspominał już o analfabetyzmie i oszustwach, a jedynie zaznaczył, że kupiectwo moskiewskie, mimo ożywienia politycznego przełomu lat pięćdziesiątych i sześćdziesiątych XIX w., nie angażowało się w życie społeczne.

Jeleński w swych wspomnieniach podjął wątek kobiety rosyjskiej. Po raz pierwszy zrobił to $\mathrm{w}$ odniesieniu do mieszczanek muromskich. Był zachwycony ich wyglądem, a zwłaszcza delikatnymi rysami twarzy i mądrymi oczyma. Jego zdaniem gdyby te kobiety ubrano w modne salonowe stroje, to od razu przeobraziłyby się w szykowne damy. Nadto dodał, że nigdzie później w miastach guberni wielkoruskich nie widział tak pięknych kobiet ${ }^{33}$. Zapewne na ten zachwyt wpływał też jego młody wiek. Przybywając do Muromia, miał 21 lat i zainteresowanie płcią piękną było naturalne.

Tego zachwytu nie wyraził już w odniesieniu do kobiet wywodzących się ze sfer ziemiańskich. Jego zdaniem ziemianki były całkowicie w cieniu swoich mężów, a nadto słabo wykształcone. Otrzymywały jedynie tzw. wychowanie domowe, a tylko nieliczne kształciły się na pensjach. Rodzice zabraniali im czytać, obawiając się, że wszelkie lektury pobudzą ich marzenia i w ostateczności wprowadzą je na drogę

${ }^{31} \mathrm{~W}$ tym stwierdzeniu jest sporo racji. Aleksander II w 1857 r. powołał Tajny Komitet do Spraw Włościańskich. W jego skład wchodzili ziemianie o poglądach zachowawczych i sprawa reformy włościańskiej utknęłaby w miejscu, gdyby nie postawa ziemiaństwa z tzw. guberni litewskich (kowieńskiej, wileńskiej i grodzieńskiej). Tamtejsze ziemiaństwo za pośrednictwem generała-gubernatora Władimira Nazimowa wystosowało do cara adres z prośbą o pozwolenie na likwidację poddaństwa w swych dobrach. $\mathrm{Z}$ tą chwilą prace nad reformą włościańską w Imperium Rosyjskim nabrały dynamiki. Szerzej por. [J. Gieysztor], Litwa przed rokiem 1863, Lwów 1888, s. 21-25; L. Bazylow, Dzieje Rosji 1801-1917, Warszawa 1977, s. 216.

32 „Русская старина” 127 (1906), № 11, s. 680-683. Por. O. Jeleński, Rozmyślania i wspomnienia..., s. 37-38.

33 „Русская старина” 127 (1906), № 11, s. 709-710. Por. O. Jeleński, Rozmyślania i wspomnienia..., s. $67-68$. 
dążącą do przemian w położeniu kobiety rosyjskiej. Jednym słowem wychowanie kobiet $\mathrm{z}$ wyższych sfer ziemiańskich sprowadzało się do tego, by umiały grać na fortepianie, były obojętne na wszystko i wszystkich, umiały błyszczeć w towarzystwie i dążyły do udanego zamążpójścia ${ }^{34}$. Jego zdaniem Polki ziemianki były daleko lepiej wykształcone, dbały o gospodarstwo domowe, a dzieci wychowywały zgodnie z patriotycznymi i religijnymi zasadami. Wielką zaletę Polek stanowiła zdolność do poświęceń dla innych. Jeleński miał tu na myśli fakt, że tysiące polskich kobiet poszło na dobrowolne zesłanie za swoimi mężami i narzeczonymi. Jednakże zaraz dodał, że nie można mówić, iż wśród Rosjanek nie było kobiet kierujących się zaszczytnymi pobudkami, a najlepszy przykład stanowiły żony dekabrystów ${ }^{35}$. Jednakże skali zjawiska nie należy porównywać.

Z późniejszej perspektywy Jeleński zmodyfikował swoją opinię o kobietach rosyjskich. Stwierdził, że są bardziej energiczne niż mężczyźni, że potrafią po śmierci męża zrobić wszystko, by zapewnić dzieciom odpowiednie warunki bytowania. Dodał także, że Rosjanki są wiernymi żonami ${ }^{36}$.

Sporo miejsca w swych wspomnieniach poświęcił kwestii popa prawosławnego w społeczności parafialnej. Już w dzieciństwie, a potem w korpusie kadeckim nasłuchał się wiele gorszących opowieści o duchowieństwie prawosławnym. Intrygowało go, skąd się wzięło powiedzenie "pop zdziera z żywego i umarłego"37. Powiedzenie to, niestety, było prawdziwe, a odnosiło się do duchownych prawosławnych mieszkających w parafiach wiejskich. Chłopi byli bardzo biedni, stąd też pop, by zapewnić jako taką egzystencję swojej, czasami dość licznej rodzinie, odmawiał odprawienia nabożeństwa, dopóki nie otrzymał odpowiedniej sumy pieniędzy. Jeleński opisał sytuację materialną jednego z popów, z którym zaprzyjaźnił się i regularnie bywał przez pół roku w jego domu. On i jego rodzina żyli w ewangelicznym ubóstwie. Przyszłoby im umierać z głodu, gdyby ojciec Symeon - bo z nim się właśnie zaprzyjaźnił - nie posiadał zdolności do majsterkowania. Wykonywał więc roboty ślusarskie w obrębie swojej parafii i za to pobierał niewielkie opłaty.

34 „Русская старина” 127 (1906), № 11, s. 718. Por. O. Jeleński, Rozmyślania i wspomnienia..., s. 71.

35 Postawa dziesięciu Rosjanek i jednej Francuzki, które poszły na Syberię za skazanymi w grudniu 1825 r. dekabrystami, zyskała światowy rozgłos. Na ten temat powstało wiele publikacji prasowych, oddzielnych opracowań, a nawet wierszy i powieści. Jeleński musiał dobrze znać ten problem, ale też mieć wyobrażenie o liczbie Polek, które dobrowolnie podążyły za mężami czy narzeczonymi na zesłanie syberyjskie. Nie pomylił się więc, powiadając, że tysiące kobiet polskich dobrowolnie znalazło się na Syberii, by dzielić los razem z mężami czy narzeczonymi. Zakłada się, że wśród ok. 40 tys. Polaków zesłanych w głąb Imperium Rosyjskiego po upadku powstania styczniowego kobiety mogły stanowić do $10 \%$. Szerzej zob. W. Caban, L. Michalska-Bracha, Kobiety powstania styczniowego na Syberii. Zesłanki do Usola i Kunguru, w: Postawy i aktywność kobiet w czasie powstania styczniowego 1863-1864, red. T. Kulak, J. Dufrat, M. Piotrowska-Marchewa, Wrocław 2013, s. 169.

36 „Русская старина” 128 (1906), № 10, s. 229.

37 „Русская старина” 127 (1906), № 11, s. 685. Por. O. Jeleński, Rozmyślania i wspomnienia..., s. 43. 
Jeleński zwrócił uwagę, że popa nie darzyli szacunkiem ani chłopi, ani dziedzice. Nie rozumiał takiej postawy parafian wobec popa, bo - jak podkreślał - inna sytuacja panowała w parafiach katolickich na Litwie, gdzie zarówno dla chłopów, jak i ziemian ksiądz był autorytetem. Tę sytuację tłumaczył Jeleński m.in. tym, że duchowieństwo katolickie było lepiej wykształcone i nie ograniczało się do odprawiania tylko nabożeństw, ale starało się, jeśli tak można powiedzieć, żyć codziennością swych parafian. Czy Jeleński miał rację? Trudno na tak postawione pytanie odpowiedzieć.

Przy okazji opisywania trudnej sytuacji materialnej duchowieństwa prawosławnego Jeleński wystąpił w obronie księży katolickich, jakoby byli nietolerancyjni. Brak tolerancyjności zarzucały księżom katolickim władze carskie i wyższa hierarchia Cerkwi prawosławnej. Chodziło głównie o to, że księża katoliccy nie wyrażali zgody na zawarcie małżeństw mieszanych. Jeleński powiadał, że taka postawa księży była prawidłowa, bo przepisy prawne dla małżeństw mieszanych faworyzowały prawosławnych. Jego zdaniem istniało tylko jedno wyjście z tej sytuacji, a mianowicie zmienić obraźliwe prawo o ślubach mieszanych i księża katoliccy nie będą mieć powodów do jego krytyki.

Zdaniem Jeleńskiego zarzut o nietolerancyjności należało postawić nie duchowieństwu katolickiemu, a właśnie prawosławnemu, bo jakże mówić o tolerancji, kiedy najwyżsi hierarchowie Cerkwi prawosławnej zalecali odbierać dzieci staroobrzędowcom i wychowywać je w religii prawosławnej ${ }^{38}$.

Wiele miejsca poświęcił Jeleński wzajemnym relacjom polsko-rosyjskim w $1861 \mathrm{r}$. Akurat w tym czasie, jak już wspominałem, jego pułk stacjonował w Moskwie, a on sam aktywnie uczestniczył $\mathrm{w}$ wielu dyskusjach toczących się $\mathrm{w}$ różnego rodzaju kółkach, które skupiały wojskowych, młodzież studencką czy inteligencję Moskwy. Przebywał na wieczorach organizowanych przez Henryka Wyzińskiego ${ }^{39}$, profesora historii Uniwersytetu Moskiewskiego ${ }^{40}$, znanego pisarza Iwana Iwanowicza Łażecznikowa (1792-1869) i hrabinę „A” będącą w bliskich kontaktach z „Hercenem”. Na spotkaniach tych dyskutowano o zachodzących przemianach społeczno-politycznych w Rosji i o sprawie polskiej.

Podczas wieczorów u prof. Wyzińskiego wiele rozmawiało się o słowianofilach i zapadnikach (okcydentalistach). Zdaniem Jeleńskiego poglądy słowianofilów były wydumane w gabinetach, bo jak można głosić hasła, że Polak, Czech i Słowak kiedy tylko przyjmą prawosławie, stworzą wielką rodzinę razem z Rosją ${ }^{41}$. Dyskutowano też o antypolskich publikacjach Katkowa. Zapewne do tych dyskusji dochodziło

38 „Русская старина” 127 (1906), № 11, s. 694. Por. O. Jeleński, Rozmyślania i wspomnienia..., s. 51.

39 Jeleński po latach mylnie zapisał nazwisko profesora jako Wydynskij.

40 Bogatą drogę życiową Henryka Wyzińskiego, urodzonego w Warszawie w 1834 r., absolwenta gimnazjum lubelskiego, później studenta i profesora Uniwersytetu Warszawskiego, profesora Szkoły Głównej w Warszawie, a od jesieni 1862 r. współpracownika Hotelu Lambert w Paryżu opisał Jerzy Zdrada w publikacji Droga emigranta (Henryk Wyziński 1834-1879), „Kwartalnik Historyczny" (78) 1971, nr 1, s. 49-68.

41 „Русская старина” 128 (1906), № 10, s. 207. 
z inspiracji samego profesora, który przez kilka lat przyjaźnił się z nim² ${ }^{42}$, bo obydwaj byli zwolennikami poglądów prezentowanych przez okcydentalistów. Dyskutanci zgadzali się, że w poglądach Katkowa trudno dopatrzyć się głębszej myśli, że nie warto z nim dyskutować, bo on uważa, że jest najmądrzejszy ze wszystkich, że w każdej sprawie ma rację, a jeżeli ktoś prezentuje odmienne stanowisko, to wobec dyskutanta staje się agresywny ${ }^{43}$.

Nieco odmienny charakter miały spotkania u Łażecznikowa. Jeleński najprawdopodobniej znalazł się tam dlatego, że wcześniej zapoznał się z jego wieloma utworami. U pisarza dyskutowano głównie o nowych tendencjach w literaturze i publicystyce. Na ile podnoszono tam szeroko rozumiane kwestie polskie, trudno się zdecydowanie wypowiedzieć. Można wszakże przypuszczać, że Łażecznikow opowiadał o swoich kontaktach z samym Adamem Mickiewiczem i jego twórczości.

Łażecznikow bacznie obserwował zachowanie społeczności polskiej w Moskwie, zwłaszcza studenckiej ${ }^{44}$. Znalazło to później odbicie w jego utworze Wnuczka pancyrnogo bojarina ${ }^{45}$ (Внучка панцырного боярина). Publikacja tego dzieła spowodowała aresztowanie i zsyłkę na Syberię niektórych działaczy kółek młodzieżowych, a to dlatego, że Łażecznikow posłużył się zbyt prostymi inicjałami w odniesieniu do nich i policja miała ułatwione zadanie z identyfikacją. Najprawdopodobniej postąpił tak świadomie, bo chodziło mu o dołączenie się do obowiązującego nurtu potępiania polskości w literaturze i publicystyce w czasie powstania styczniowego i bezpośrednio po jego upadku ${ }^{46}$.

Najliczniejsze, a zarazem najgorętsze dyskusje, w których uczestniczył Jeleński, odbywały się u hrabiny „A”. Początkowo na tych spotkaniach nie dyskutowano o sprawie polskiej. Zmiana nastąpiła po tzw. wydarzeniach warszawskich $1861 \mathrm{r}^{47}$ $\mathrm{Na}$ jednym ze spotkań stwierdzono zgodnie, że nie wystarczy sympatyzować z Polakami, a trzeba zaoferować im konkretną pomoc, by mogli żyć w wolnej ojczyźnie. Niespodziewanie jeden z uczestników wyrecytował utwór Kornela Ujejskiego $Z$ dymem pożarów. Zebrani przyjęli to gromkimi oklaskami. Atmosfera

${ }^{42}$ Przyjaźń Wyzińskiego z Katkowem nie powinna budzić zdziwienia, bo do przełomu lat pięćdziesiątych-sześćdziesiątych XIX w. uważał się on za przyjaciela Polaków. Redagowany przez niego „Russkij wiestnik”, mimo cenzury, niejednokrotnie przejawiał propolskie nastawienie. W 1857 r. Katkow wciągnął Wyzińskiego do współpracy z tym pismem. Por. J. Zdrada, Droga emigranta..., s. 51.

43 „Русская старина” 128 (1906), № 10, s. 209.

${ }^{44} \mathrm{O}$ aktywności politycznej polskiej młodzieży studenckiej w dobie powstania styczniowego szeroko pisze T.F. Fiedosowa, Polskie organizacje patriotyczne w Moskwie 1857-1866, tłum. M. Skowronek, przygot. do dr. i koment. J. Skowronek, Warszawa 1984, s. 25-145.

45 Внучка панцьрного боярина została opublikowana w czasopiśmie: „Всемирный Труд” (1868), № 1-4. Pismo, jako miesięcznik, ukazywało się w Petersburgu w latach 1867-1872 i według krytyków nie prezentowało zbyt wysokiego poziomu.

46 Por. „Русская старина” 128 (1906), № 10, s. 219-220.

47 Chodzi tu o wydarzenia z 27 lutego 1861 r., kiedy podczas manifestacji w Warszawie było pięciu zabitych, a w czasie manifestacji na pl. Zamkowym 8 kwietnia tegoż roku - ponad 100 ofiar. 
stała się jeszcze bardziej podniosła, gdy jeden z pisarzy rosyjskich odczytał najpierw po polsku, a później po rosyjsku wiersz polskiego poety na cześć Nikołaja Niekrasowa, klasyka rosyjskiej literatury, sympatyzującego z rewolucyjnymi demokratami. Wiersz ów był swoistego rodzaju przesłaniem dla Rosjan, nawołującym do zgody z Polakami ${ }^{48}$. Jeleński po latach przyznał, że podczas tego wieczoru uwierzył w pomoc społeczeństwa rosyjskiego w zabiegach Polaków o odzyskanie niepodległości i z radości o mało nie napłynęły mu łzy do oczu. Inaczej do tych wydarzeń odniósł się Ludwik Zwierzdowski ${ }^{49}$, starszy wiekiem i rangą, związany z powstałym w armii rosyjskiej na fali odwilży posewastopolskiej Kołem Oficerów ${ }^{50}$. Wytłumaczył on o 8 lat młodszemu koledze, że sympatia rosyjskiej inteligencji do Polaków szybko przeminie i nie należy liczyć na jakąkolwiek pomoc z jej strony w dążeniach Polaków do niepodległości.

Jeleński zgodził się z poglądem Zwierzdowskiego i nadmienił dodatkowo w swych wspomnieniach, że wielu Rosjan sympatyzujących ze sprawą polską $\mathrm{z}$ chwilą wybuchu powstania styczniowego natychmiast je potępiło, a byli i tacy, jak recytujący na spotkaniu u hrabiny „A” $Z$ dymem pożarów, że przystąpili do tłumienia polskiego „miatieża” ${ }^{2}$.

Oddzielny fragment poświęcił Katkowowi ${ }^{52}$. Wspominałem już, że poznał on redaktora „Moskowskich wiedomosti” („Московские ведомости”) już w 1859 r., kiedy jako kadet pojawił się na jednym ze spotkań towarzyskich odbywających się u rodziny Aleksiejewych. Nadmieniałem też, że Jeleński wsłuchiwał się w opinie wydawane o Katkowie przez rosyjską inteligencję i zamieścił je w swych wspomnieniach. Wreszcie doszło do ich bezpośredniego spotkania, a powodem były korespondencje Jeleńskiego zamieszczane w „Kraju” ${ }^{3}$. Katkow uważnie śledził

48 Niestety, Jeleński podał tylko zapis wiersza w bardzo dowolnym (zapewne swoim) tłumaczeniu na język rosyjski, „Русская старина” 128 (1906), № 10, s. 236. Przekład tego zapisu na język polski nie pozwala ustalić autora wiersza. Można przypuszczać, że mógł nim być Mieczysław Romanowski, poeta romantyk, który zginął w czasie powstania styczniowego.

49 Ludwik Zwierzdowski (1829-1864) studiował w Akademii Sztabu Generalnego w Petersburgu. Był aktywnym członkiem powstałego w armii rosyjskiej w 1860 r. Koła Oficerów. Pod koniec 1862 r. znalazł się w Moskwie i brał udział w wielu wieczorach dyskusyjnych. Po wybuchu powstania otrzymał dymisję z wojska i oddał się pod rozkazy Rządu Narodowego. Po przegranej bitwie opatowskiej w końcu lutego 1864 r. dostał się do niewoli i rozstrzelano go w Opatowie.

${ }^{50}$ Działalność Koła Oficerów i kwestia polsko-rosyjskiej współpracy rewolucyjnej w armii carskiej najpełniej zostały przedstawione w publikacji: W. Djakow, I. Miller, Ruch rewolucyjny w armii rosyjskiej a powstanie styczniowe, Wrocław 1967.

${ }^{51}$ Ów recytator był bliskim współpracownikiem generała-gubernatora Michaiła Murawjowa na Litwie, „Русская старина” 128 (1906), № 10, s. 237.

${ }^{52} \mathrm{~W}$ historiografii polskiej sprawie Katkowa poświęcono kilka publikacji. Najszerzej na temat jego przemian ideowych i postawy wobec Polaków wypowiedział się H. Głębocki, Kresy imperium. Szkice i materialy do dziejów polityki Rosji wobec jej peryferii (XVIII-XXI wiek), Kraków 2006, s. 245-306.

53 Jeleński mylił się, powiadając, że do spotkania doszło w 1880 r. „Kraj” wychodził od 1882 r., a pierwsze jego korespondencje, jak wspominałem wcześniej, mogły się pojawić w $1883 \mathrm{r}$. 
przedsięwzięcia Piltza i Spasowicza i wszystko to, co publikowano na łamach ich pisma. Zaniepokoiły go korespondencje Jeleńskiego z Powołża, w których napomknął o możliwościach eksportu z Królestwa Polskiego pewnych produktów przemysłowych do tej części Rosji. Z kolei w innej korespondencji zamieścił informację, że niektórzy Kozacy na Powołżu znają język polski, bo pewne przedmioty w ich domach mają polskie nazwy ${ }^{54}$. Na tego typu wiadomości zamieszczone w „Kraju” ostro zareagował Katkow ${ }^{55}$. Jeleński będąc przy okazji w Moskwie, postanowił złożyć mu wizytę i sprawę wyjaśnić. Po pokonaniu wielu trudności, posługując się przy tym tupetem, dostał się do gabinetu Katkowa. Rozmowa przebiegała w nerwowej atmosferze, a Katkow co chwila powtarzał Jeleńskiemu, że jego korespondencje wpisują się w szeroko zakrojoną „polską intrygę”. Jeleński starał się na każdym kroku wyperswadować redaktorowi „Moskowskich wiedomosti”, że nie ma racji, chociażby dlatego, że „Kraj” to pismo ugodowe i w kręgu jego redaktorów nie da się znaleźć osoby, która by nie zachowywała się lojalnie wobec Rosji. Dodał zaraz, że każdy tekst publikowany w „Kraju” wcześniej poddawany jest ścisłej cenzurze i gdyby cokolwiek znaleziono w nim nieprawomyślnego, nie dopuszczono by do publikacji. Katkow był jednak nieugięty, że informowanie czytelników „Kraju” o możliwości podejmowania jakichś, bliżej nieokreślonych przedsięwzięć gospodarczych ze strony przedsiębiorców Królestwa Polskiego na Powołżu to szeroko zakrojony zamysł, który wpisuje się w „polską intrygę". Katkow, by udowodnić Jeleńskiemu, że ma rację, odwołał się do spisku zorganizowanego w Kazaniu w 1863 r. ${ }^{56} \mathrm{Na}$ co Jeleński mu odpowiedział, że argument jest chybiony, bo spisek ten tworzyli nie tylko szaleni Polacy, ale i Rosjanie. Nie dało się tego podważyć, ale Katkowa w niczym to wszystko nie przekonało i oświadczył Jeleńskiemu, że Rosjanie nie mogą przestać walczyć z Polską, dopóki nie dojdzie do jej pogrzebu i na grobie nie zostanie postawiony krzyż. Ten $\mathrm{z}$ kolei oświadczył mu, że w narodzie polskim, mimo prowadzonych prześladowań, wcale nie osłabiono ducha. Polacy nie dadzą się złamać.

Tę rozmowę Jeleński zrekapitulował stwierdzeniem, iż można być fanatykiem, można być propagandzistą, ale nie można demoralizować ludzi kłamstwami i napuszczaniem jednych przeciw drugim ${ }^{57}$.

54 „Русская старина” 128 (1906), № 10, s. 210-213. Niestety nie ustalono daty tych korespondencji.

55 Polemika zapewne została podjęta na łamach „Moskowskich wiedomosti”, ale nie udało się dokonać odpowiednich ustaleń.

56 Spisek kazański („казанский заговор”) w dawnej historiografii rosyjskiej przedstawiano jako element polskiej intrygi. Polacy wspólnie z Tatarami i buntującymi się chłopami rosyjskim mieli doprowadzić do zbrojnego wystąpienia, które w konsekwencji byłoby na rękę powstańcom styczniowym. Z kolei w historiografii radzieckiej przedstawiono go jako element polsko-rosyjskiej współpracy rewolucyjnej. Ocena tych zdarzeń jest skomplikowana, bo historyk dysponuje w zasadzie tylko materiałami śledczymi. Najnowsze, co nie oznacza, że ostateczne, ustalenia w sprawie spisku kazańskiego zob. T.F. Fiedosowa, op. cit., s. 145-179. Przy okazji warto nadmienić, że problem polsko-rosyjskiej współpracy rewolucyjnej w dobie powstania styczniowego czeka na swego historyka.

57 Jeleński zamieścił informację krążącą wśród Polaków w Moskwie, że Katkow mimo iż tak nienawidził Polaków, to jako korepetytora swego syna zdecydował się zatrudnić polskiego studenta, bo ci, 
Ciekawe uwagi zamieścił Jeleński odnośnie do oddziaływania antypolskiej propagandy uprawianej przez „Moskowskije wiedomosti”. Jego zdaniem pod koniec lat siedemdziesiątych XIX w. w pewnych kręgach społecznych dystansowano się wobec tej gazety. Jeleński dla zobrazowania problemu podał tylko jeden przykład odnoszący się do kupców z Niżnego Nowogrodu. Ze swej strony dodam, że podobne informacje odnotowali w swych pamiętnikach niektórzy zesłańcy postyczniowi ${ }^{58}$. Trudno jednakże kusić się na jakiekolwiek próby określenia skali zjawiska dotyczącego dystansowania się społeczeństwa rosyjskiego od informacji, jakie podawały „Moskowskije wiedomosti” na temat polskich „miatieżnikow”.

Z lektury Rozmyślań $i$ wspomnień Polaka wynika, że sam Jeleński widział możliwość ułożenia dobrych stosunków między Polakami i Rosjanami. Na przeszkodzie do tego porozumienia stała głównie „patriotyczna historiografia”. Wierzył, że przyjdzie czas na obiektywną ocenę przez historiografię rosyjską postaw Polaków wobec Rosji na przestrzeni całego XIX w. Wierzył, że wtedy nie będzie się obwiniać jego rodaków o brak cierpliwości i krańcową zapalczywość. Uważał on, że Polacy i tak wykazali nadmiar cierpliwości w sytuacji, kiedy rosyjski aparat administracyjno-policyjny stosował najróżniejsze formy represji, zwłaszcza wobec Polaków mieszkających w guberniach zachodnich Imperium Rosyjskiego. Jego zdaniem społeczeństwo rosyjskie, mimo różnych form propagandy, dobrze odnosiło się do Polaków. On sam cieszył się szacunkiem wśród rosyjskiej kadry oficerskiej i społeczeństwa rosyjskiego. Nikt go nie zmuszał do przejścia na prawosławie. Nosząc rosyjski mundur, nie musiał się wyrzekać polskości. Zadbał też o wychowanie swych dzieci w duchu polskim i katolickim. Jednym słowem należał do tej grupy Polaków noszących carski mundur, która nie zapominała o polskości i religii katolickiej. Swą postawą potwierdził, że noszenie munduru rosyjskiego oficera wcale nie wymagało odejścia od polskości. Tu dodajmy, że problem służby Polaków w carskim korpusie oficerskim w XIX w. czeka na swego badacza ${ }^{59}$.

Kończąc swe wspomnienia, Jeleński zaznaczył, że jeżeli będzie zainteresowanie czytelników „Russkoj stariny”, to on przedstawi dalszą ich część. Niestety, kolejne fragmenty się nie pojawiły. Szkoda, bo zapewne znaleźlibyśmy w nich opisy jego życia po powrocie $\mathrm{w}$ rodzinne strony, a zarazem wiele ciekawych opinii na temat relacji polsko-rosyjskich w Kraju Północno-Zachodnim. Trudno zgadywać, co

zdaniem Jeleńskiego, daleko sumienniej wywiązywali się ze swych obowiązków niż ich rosyjscy koledzy. Trudno tę informację zweryfikować. Por. „Русская старина” 128 (1906), № 10, s. 221.

58 Por. W. Caban, Rosjanie i Sybiracy o zesłańcach postyczniowych, w: Польские ссыльныьше в Сибири во второй половине XVIII-начале XX века в восприятии россииской администрации, переселениев и коренных народов Сибири, ред. С.А. Мулина, Омск 2015, s. 36.

59 Zob. W. Caban, Wpływ służby Polaków $w$ armii carskiej na świadomość narodowa $w$ dobie międzypowstaniowej, w: Przełomy w historii. XVI Powszechny Zjazd Historyków Polskich, Wrocław, 15-18 września 1999 roku. Pamiętnik, t. 2, cz. 2, Toruń 2000, s. 73-85. Por. też: Polak w carskim mundurze. Wspomnienia Aleksandra Skolimowskiego (1817-1895), oprac. W. Caban, J. Szczepański, Kielce 2015. 
stanęło na przeszkodzie, że dalsze teksty się nie ukazały. Być może Jeleński zmarł, ale też nie należy wykluczać, że nie było tzw. zainteresowania czytelników, a raczej redakcji „Russkoj stariny”, bo autor Rozmyślań $i$ wspomnień Polaka czasami podkreślał wyższość cywilizacyjną poszczególnych warstw i grup społeczeństwa polskiego nad społeczeństwem rosyjskim. O ile cenzura na fali odwilży politycznej zezwoliła na druk dwóch części tych wspomnień w 1906 r., to w następnych latach zapewne wzmogła swoją czujność. Nie można zatem wykluczać, że w archiwum „Russkoj stariny” moglibyśmy odnaleźć dalszy tekst wspomnień Jeleńskiego. Możliwe też, że leży on na półce w jakimś archiwum lub bibliotece.

\section{Oktawian Jeleński - a Pole in the Tsarist Military Uniform. On the Russians and Polish-Russian Relations in the Nineteenth Century}

\section{Abstract}

In his "Meditations and Memories of a Pole", Oktawian Jeleński characterised the everyday life in the country led by the military men, landed gentry, peasants, merchants, Russian women, and Orthodox clergy. In addition, he devoted a lot of attention to the Polish-Russian relations during the January Uprising (1863-64). He took part in discussions held in salons in Moscow in which their participants sympathised with Poles.

In the 1880s, he started collaboration with the Polish weekly Kraj (Country) published in St Petersburg, to which he wrote texts on the lives of Poles from various regions of the Russian Empire. Undoubtedly, Jeleński took a conciliatory position, but he strongly criticized all undertakings of the Russian administrative and police apparatus aimed at weakening the Polish spirit, especially in the Northwestern Krai. As for himself, Jeleński saw the possibility of establishing good relations between Poles and Russians, hampered in his opinion by the so-called patriotic historiography. He believed that the time would come for an objective assessment in the Russian historiography on the subject of Poles' attitudes towards Russia throughout the nineteenth century. He believed that at that time his countrymen would not be blamed for their lack of patience and extreme hot-headedness.

Jeleński's memories testify that a Pole wearing the tsarist military uniform did not have to deny his Polishness and the Catholic faith.

\section{Октавиан Еленский - поляк в царском мундире. О русских и польско-российских отношениях \\ в XIX веке}

\section{Аннотация}

Октавиан Еленский в своих «Размышлениях и воспоминаниях поляка» охарактеризовал жизнь военных в глубинке, помещиков, крестьян, купечества, российских женщин, православного духовенства. Кроме того, он уделил много внимания польско-российским отношениям в период Январского восстания. Он принимал участие в беседах, которые велись в московских салонах, во время которых симпатизировали полякам. 
В 1880-х годах Еленский стал сотрудничать с петербургским «Краем», в котором он печатал информацию о жизни поляков из разных регионов Российской империи. Без сомнения Еленский находился на примиренческих позициях, но подвергал резкой критике всякие начинания российского административно-полицейского аппарата, направленные на ослабление польского духа, особенно в Северно-Западном Крае. Еленский, лично, видел возможность наладит хорошие отношения между поляками и русскими. Препятствием на пути к этому соглашению стала т.н. патриотическая историография. Он верил, что придет время объективной оценке российской историографией отношения поляков к России в течение всего XIX века. Он верил, что тогда его соотечественников не будут обвинять в нехватке терпения и крайней запальчивости.

Мемуары Еленского являются свидетельством того, что поляк в царском мундире не должен был отрекаться от польскости и католицизма.

\section{Bibliografia}

\section{Źródła}

[Gieysztor J.], Litwa przed rokiem 1863, Lwów 1888.

Jeleński O., Przemyst naftowy w Rosyi, odbitka „Kraju” (1888).

Jeleński O., Rozmyślania i wspomnienia Polaka, oprac. W. Caban, J. Szczepański, w: Mentalność rosyjska a Polska, red. ks. E. Walewander, Lublin 2015, s. 21-72.

Polak $w$ carskim mundurze. Wspomnienia Aleksandra Skolimowskiego (1817-1895), oprac. W. Caban, J. Szczepański, Kielce 2015.

Еленский О., Мои воспоминания о забытом корпусе, „Русская старина” 83 (1895), № 6, s. 143-169; № 11, s. 185-203.

Еленский О., Мысли и воспоминания поляка, „Русская старина” 127 (1906), № 11, s. 670714; 128 (1906), № 10, s. 200-242.

\section{Opracowania}

Bazylow L., Dzieje Rosji 1801-1917, Warszawa 1977.

Caban W., Michalska-Bracha L., Kobiety powstania styczniowego na Syberii. Zesłanki do Usola i Kunguru, w: Postawy i aktywność kobiet w czasie powstania styczniowego 1863-1864, red. T. Kulak, J. Dufrat, M. Piotrowska-Marchewa, Wrocław 2013, s. 163-189.

Caban W., Rosjanie i Sybiracy o zesłańcach postyczniowych, w: Польские ссыльныьие в Сибири во второй половине XVIII-начале XX века в восприятии россицской администрации, переселенцев и коренных народов Сибири, ред. С.А. Мулина, Омск 2015, s. 31-39.

Caban W., W stużbie imperium, czy ofiary imperium? Polacy $w$ carskim korpusie oficerskim w XIX wieku, w: Ofiary imperium. Imperia jako ofiary. 44 spojrzenia, red. A. Nowak, Warszawa 2010, s. 214-226.

Caban W., Wpływ służby Polaków $w$ armii carskiej na świadomość narodowa $w$ dobie międzypowstaniowej, w: Przełomy w historii. XVI Powszechny Zjazd Historyków Polskich, Wrocław, 15-18 września 1999 roku. Pamiętnik, t. 2, cz. 2, Toruń 2000, s. 73-85.

Djakow W., Miller I., Ruch rewolucyjny w armii rosyjskiej a powstanie styczniowe, Wrocław 1967. Fiedosowa T.F., Polskie organizacje patriotyczne w Moskwie 1857-1866, tłum. M. Skowronek, przygot. do dr. i koment. J. Skowronek, Warszawa 1984.

Giller A., Korpus Kadetów w Brześciu Litewskim, w: idem, Z wygnania, t. 1, Lwów 1870, s. 33-60. 
Głębocki H., Kresy imperium. Szkice i materiały do dziejów polityki Rosji wobec jej peryferii (XVIII-XXI wiek), Kraków 2006.

Kmiecik Z., „Kraj” za czasów redaktorstwa Erazma Piltza, Warszawa 1969.

Łukawski Z., Ludność polska w Rosji 1863-1914, Wrocław 1978.

Śliwowska W., Zesłańcy polscy w Imperium Rosyjskim w pierwszej połowie XIX wieku, Warszawa 1998.

Zdrada J., Droga emigranta (Henryk Wyziński 1834-1879), „Kwartalnik Historyczny” 78 (1971), nr 1, s. 49-68.

Zdrada J., Jarosław Dąbrowski 1836-1871, Kraków 1973.

Бригадин П.И., Лукашевич А.М., Мятежный корпус. Из истории Александровского Брестского кадетского корпуса (1842-1863), Минск 2007.

Горизонтов Л.Е., Парадоксы имперской политики: поляки в России и русские в Польше (ХIX - начало XX в.), Москва 1999.

Мартианова И.Ю., Воспоминания поляка о старообрядиах России (вторая половина ХІХ в.), w: Поляки в России: Эпохи и судьбы, Краснодар 2009, s. 44-50.

Wiesław Caban, prof. dr hab., pracuje w Instytucie Historii Uniwersytetu Jana Kochanowskiego w Kielcach. Zajmuje się historią Polski XIX w., a w ostatnich latach dziejami Polaków w Imperium Rosyjskim w XIX w., w tym zesłaniami syberyjskimi (caban@ujk.edu.pl).

Wiesław Caban, Prof. dr. hab., works at the Institute of History of Jan Kochanowski University in Kielce; his scholarly interests cover the history of Poland in the $19^{\text {th }}$ century and, in recent years, the history of Poles in the Russian Empire in the $19^{\text {th }}$ century, including Siberian exiles (caban@ujk.edu.pl). 